\title{
An Investigation of the Relationship between EFL Pre-Service Teachers' Writing Proficiency and their Learning Environment Perception
}

Submitted By

\author{
Yomna Ayman Gamal El-deen \\ Language Instructor at Fayoum University \\ Dr. Mohammed Farouk Abd Elsami' \\ Professor of EFL Curriculumand Instruction \\ Dean of Faculty of Education-FayoumUniversity \\ Dr.Hanaa Ezzat Mohammed \\ AssistantProfessor of Educational Psychology \\ Faculty of Education-FayoumUniversity

\section{Dr.Abeer El-Sayed M. Abo Zaid \\ Faculty of Education-Fayoum University} \\ Lecturer of EFL Curriculum and Instruction
}

\section{ABSTRACT}

This research aimed at investigating the relationship between EFL pre-service teachers' writing proficiency and their learning environment perception. The research participants were (80) of the EFL pre-service teachers enrolled in the first year-English Language Departemnt at the Faculty of Education/Fayoum University. The data were collected by using two instruments designed by the researcher: a writing proficiency test and a learning environment perception questionnaire. Results showed that there was a positive correlation between the research participants' writing proficiency and their learning environment perception.Some recommendations and suggestions were presented for further research.

Keywords: writing proficiency, learning environment perception, EFL pre-service teachers

\section{Introduction}

Nowadays, English is becoming important as more than 300 million persons are using it as they are native speakers and more than 400 million persons are using it as second or foreign language users. In addition, English language is used in different contexts, so it is 
necessary to understand and analyze students' beliefs and perceptions regarding learning English either as a foreign or as a second language. $(\operatorname{Rad}, 2010)$.

Hayati (2015) declared that human being is not only an individual person, but also he/she is a social one who needs to communicate and uses language as a means for communication. Thus,people want to learn English because it is considered an international language that can be used for general or specific purposes and in formal and informal situations. In the classroom context, the students' perceptions, beliefs, attitudes and metacognitive knowledge are considered important elements in the learning process.

Klimova (2014) stated that the communicative goal is achieved through the four language skills as they are used in everyday communicative situations. These skills are divided into receptive and productive skills. The receptive skills are listening and reading and the productive ones are writing and speaking. Regarding the productive skills, they are developed least during English language teaching.

Writing in one's first language, known as the mother tongue, or in a second or foreign language is considered a too challenging skill to do perfectly. This fact can be applied to school children or even professionals and it is related to the complicated cognitive processes included in the writing skill. (Mastan,Maarof\&Embi,2017).Nacira (2010) confirmed that the four skills of the foreign language teaching and learning are complex ,especially writing and half of the world's population do not know how they can write effectively as writing needs some steps to be followed, enough time, and practice.

Huy (2015) stated that writing is considered one of the most important skills, especially in work fields and it is a reason for success at university, yet many high school students do not realize this fact. The result is that there are many mistakes in students' written works. In addition, Nik et al. (2010) declared that writing 
effectively helps students to achieve three important goals: (1) it supports grammatical structures, idioms and vocabulary,(2) it provides chances for them to use language without being afraid and (3) writing improves the other language skills including fluency, accuracy and appropriateness. Writing also enhances communication and conveying meanings and messages as well.

Ismail (2011) stated that during the writing classes, learners are expected to be offered adequate time to develop their writing skill. Writing is certainly an important element of learning English language. This importance is related to the fact that it reinforces grammatical structures, vocabulary and idioms that are taught to students. Writing should receive more attention in English language classes in order to prepare learners to cope with the communicative demands of real life situations and that can be achieved by exposing students to the writing process. In addition, writing skills can be developed when the learners' interests are recognized and when they are exposed to situations where they can produce authentic piece of writing.

According to the Partnership's $21^{\text {st }}$ Century Skills Framework, it is better to describe the $21^{\text {st }}$ century learning environment as the supporting system that organizes the condition in which humans learn best, systems that accommodate the unique learning needs of every learner, and supports the positive human relationships needed for effective learning.

Nijhuis (2006) confirmed that much of the recent research on student learning in higher education can be identified in terms of the $3 \mathrm{P}$ model of Biggs (1987).In light of this model, the point of contact between the student and the learning environment is the perceived learning environment that influences learning. Also, the learning process is affected by students' characteristics and it includes: (1) the amount of knowledge and skills a student has acquired, (2) the integration of newly learned information with previously learned 
information and the structure of knowledge, and (3) students' feelings in terms of their motivation and satisfaction with the course.

In fact, according to the previously mentioned studies, it can be concluded that there may be a relationship between students' writing proficiency and their learning environment perception that can affect their acquisition of the writing skills. Hence, the current research tries to investigate the relationship between the EFL pre-service teachers' writing proficiency and their learning environment perception.

\section{Statement of the Problem}

After reviewing literature, it is shown that the students' writing proficiency can be affected by the students' surrounding. Also, it is proved that there is a relationship between learning English as a foreign language and the students' learning environment perception. Thus, there is a need to study the relationship between the students' writing proficiency and their learning environment perception.

In order to tackle this problem, the current research tried to answer the following main question:

What is the correlation between EFL pre-service teacher's writing proficiency and their learning environment perception?

This main question branches out into the following sub questions:

1. What is the EFL pre-service teachers' learning environment perception?

2. What is the level of the EFL pre-service teachers' writing proficiency?

3. What is the correlation relationship between the EFL pre-service teachers' writing proficiency and their learning environment perception?

\section{Aims of the Research}

\section{The current research aims at identifying the following:}

The relationship between the EFL pre-service teachers' writing proficiency and their perception of the learning environment. 


\section{Significance of the Research}

\section{The current research may help in:}

1- Raising the instructors' awareness for paying attention to their EFL pre-service teachers' learning environment perceptions as these perceptions affect their learning.

2- Encouraging instructors, educators and curriculum designers to search for new methods to change the limited perception of the learning environment and to improve the low level of EFL preservice teachers' writing proficiency.

3- Helping EFL pre-service teachers' to discover their perceptions of their learning environment to change them as much as they can while learning English.

\section{Hypotheses of the Research}

1- There is no statistically significant correlation between the mean scores obtained by the research participants in the writing proficiency test and their mean scores in the learning environment perception questionnaire.

2- There is no statistically significant correlation between the mean scores obtained by the research participants in the writing proficiency test and their mean scores obtained in the ten pivots of the learning environment perception questionnaire.

\section{Delimitations of the Research}

A sample of (80) EFL pre-service teachers enrolled in the first yearEnglish Language Department at the Faculty of Education/Fayoum University.

\section{Definition of Terms}

\section{1- Writing Proficiency}

Rao(2016) stated that language proficiency is the ability to do something well because of training and practice and with an advancement in knowledge or skill. 
-For the purpose of the current research, the researcher develops the following operational definition:

Writing proficiency is the students' ability to write in a good way after being trained.

\section{2-Learning Environment Perceptions}

* Learning environment is defined by the Glossary of Education Reform as (2019), "The diverse physical locations, contexts, and cultures in which students learn".

* Perception is defined by the business dictionary (2019) as, "The process which people translate sensory impressions into a coherent and unified view of the world around them ".The Cambridge Dictionaries online defines the perception as, "A belief or opinion, often held by many people and based on how things seem."

-For the purpose of the current research, the researcher develops the following operational definition:

Learning environment perceptions are the students' opinions about the surrounding context of learning either inside or outside the classroom.

\section{Review of Literature}

Walsh (2010) stated that writing is important because of its increase use in higher education and in the workplace. He added that much professional communication is done through writing as proposal, memos, reports, applications and e-mails. Actually, students need writing to express themselves in many forms in their daily life.

Nik, Hamza \&Rafidee (2010) concluded that lecturers and teachers should help students to be aware of how and why they write and encourage them to write freely and fluently at the same time. This is related to that writing is an important tool for communication and the most used means of assessing learning in education systems. Students also need to interact effectively with the world. 
In addition, writing has a unique position in language teaching as its acquisition includes the integration between three other language skills which are listening, speaking and reading .Moreover, it needs mastering of such skills. Writing is considered an essential skill because it is used to express one's personality, promote communication ,develop thinking skills and reflect on others' ideas.(Klimova,2013).

Reichelt et al. (2012) showed that, in the FL writing classroom, the following criteria should be followed : using writing to reinforce the orthography, grammar and vocabulary of the target language, using fun writing assignments to engage and motivates students, using writing to teach the culture of the target language, preparing students to survive in the target language environment, preparing students to write in business and other work-related genres and using writing as a means of connecting with others around the world who are native speakers of the target language.

A number of studies showed the important role of the learning environment perceptions to change the students' beliefs regarding their learning process while learning English as a foreign language. Lizzio, Wilson and Simons (2002) conducted a study to investigate the relationship between university students' perceptions of their learning environment and their approaches of study and the academic outcomes at both university and faculty levels. It was found that teaching environment perceptions affect learning outcomes and the students' perception of the learning environment has an effect on his/her academic outcomes and the his /her academic success as well.

Dunlop (2004) stated that the learning environment includes the classroom aspects that lead to a specific feel or tone. For instance, the classroom may full of excited voices, anticipation and discovery desire or it may only full of deactivation with uncomfortable atmosphere. In fact, the university students spend about 20.000 hours in classrooms by the end of secondary stage. Hence, it is necessary to 
carry studies and obtain information from students regarding their learning environment perceptions.

Smith(2004) stated that when people are satisfied with their environment, they do better whether at the childhood or the adulthood. On the other hand, they lose motivation as the environment should be suitable to the students' academic and asocial needs. He found out that a positive classroom environment includes cohesive and cooperative teachers and students and the ideal classroom environment should be distinguished by high degrees of satisfaction, cooperation, equity and support.

Furthermore, Barr (2016) pointed out that the classroom climate can be seen as a reflection of the students' opinions regarding their academic experience. These opinions involve their perception of the classroom, their interaction with their instructor, their peers and their involvement in the classroom. All these elements develop a different perception by each student, but of there will be a shared perception by all of them. These perceptions greatly influence the students' learning, motivation, satisfaction and achievement.

As stated above, many elements constitute the knowledge acquisition of the EFL learners, especially their perception of the learning environment. Thus, the relationship between the EFL pre-service writing proficiency and their learning environment perception can be investigated to improve the teaching and learning process of English as a foreign language.

\section{Material and Method}

The method used in the current research includes the following:

1. Design of the research.

2. Participants of the research.

3. Instrumentation of the research includes:

- A writing proficiency test.

- A learning environment perception questionnaire. 
4. Research instruments implementation.

\section{Design of the Research}

The current research followed a quasi-experimental design. The research variables include the following:

* The EFL pre-service teachers' writing proficiency.

* The EFL pre-service teachers' perception of the learning environment.

\section{Participants}

The participants of the current research were the EFL pre-service teachers enrolled in the first year-English Language Departemnt at the Faculty of Education/Fayoum University. Only (80) EFL pre-service teachers participated. The reason for choosing the sample was that those participants need to know more about the English language to accomplish their assignments and tests and to know about the culture related to the English language as they are freshmen. Moreover, they need to broaden their perception of the learning environment and improve their writing proficiency level.

\section{Instruments for Data Collection}

\subsection{Writing Proficiency Test}

\subsubsection{Aims of the Writing Proficiency Test}

The writing proficiency test was prepared to measure the participants' writing proficiency level.

\subsubsection{Design of the Writing Proficiency Test}

The test was prepared and constructed by the researcher based on reviewing the previous related studies. The writing proficiency test consisted of four main writing questions about four different topics. The participants were asked to write not less than eight sentences in each question depending on some guiding ideas or guiding pictures stated in the test. The test instructions were provided at the beginning of the test and they were clear, so the participants followed them 
easily. (To see the final version of the writing proficiency test, please go to appendix $B$.p. 26).

\subsubsection{Validity of the Test}

To ensure the test validity, the writing proficiency test was submitted to specialized jury members in the field of EFL curriculum and instruction to judge the test items according to the following:

- Suitability of the test items to students' level.

- Suitability of each test item to measure the skills it is designed for.

- Suitability of the test as a whole to its intended goal (assessing writing proficiency.)

\subsubsection{Reliability of the Test}

To determine the test reliability, it was administered to a group of 30 students, as a pilot study, in the first year-English Language Department at the Faculty of Education/Fayoum University othar than those participated in the current research. Cronbach's Alfa formula was used to estimate the test reliability. It was found (0.913) which is a high level of reliability.

\subsubsection{Time of the Test}

The needed time for the writing proficiency test was calculated, after applying the pilot study, by recording the number of minutes taken by each participant to finish the administered test and dividing them by the number of the participants. The average estimated time for answering the test was $\mathbf{4 5}$ minutes.

\subsection{Writing Scoring Rubric}

\subsubsection{Aims and Construction of the Writing Scoring Rubric:}

The aim of using the writing scoring rubric was to rate the participants responses to the writing proficiency test. It was designed after reviewing previous studies related to assessing the EFL students' writing proficiency skills based on some designed writing scoring rubrics. The writing scoring rubric consists of five categories: fluency of ideas/content, organization, grammar and syntax rules (accuracy), vocabulary use and writing mechanics (conventions). 
Each category has five scoring criteria arranged from $\mathbf{5}$ to $\mathbf{1}$ as following : 5 means" Excellent", 4 means "Very Good" , 3 means "Average" , 2 means "Acceptable" and 1 means "Weak". Thus, the total score of the writing scoring rubric is $\mathbf{2 5}$ marks and as the writing proficiency test includes four questions, the overall mark is 100.

\subsubsection{Validity of the Rubric}

To ensure the rubric validity, the writing scoring rubric was submitted to specialized jury members in the field of EFL curriculum and instruction to judge the rubric items according to the following:

1. Relatedness of the parameters of the rubric to writing proficiency.

2. Suitability of the rubric to its intended goal. (Assessing writing proficiency.)

3. Suitability of the rubric for discriminating between different levels of students' proficiency.

Some modifications were made according to the jury members' comments and suggestions. (To see the final version of the writing scoring rubric, please go to appendix $C$.p. 31 ).

\subsection{Learning Environment Perception Questionnaire}

\subsubsection{Aims of the Learning Environment Perception Questionnaire}

The aim of the learning environment perception questionnaire is to investigate the EFL pre-service teachers' perception regarding their learning environment.

\subsubsection{Construction of the Learning Environment Perception Questionnaire}

The learning environment perception questionnaire was designed after reviewing previously related studies and then it was prepared by the researcher depending on previous studies (Fraser,1998; Ali, 2008; 
Khine,2001;Aldridge,Fraser\&Bell, 2012; Alzubaidi, Aldridge \& Khine, 2014).While constructing, the following elements were taken into account:

- Using clear items.

- Using simple and direct items.

- Addressing various elements related the perception of the learning environment.

\subsubsection{Content of the Learning Environment Perception} Questionnaire

The learning environment perception questionnaire consisted of $\mathbf{2 7}$ statements and they were categorized under $\mathbf{1 0}$ dimensions as following: teacher support (three statements), learner cohesiveness (three statements), involvement (three statements), investigation(three statements), task orientation (three statements), equity(two statements), curriculum (two statements), family support(two statements), social and cultural tradition of learning (three statements) and input and output opportunities(three statements). The items were put in a five-point Likert scale from 1 (almost never) to 5 (almost always).

\subsubsection{Validity of the Questionnaire}

\subsubsection{Content Validity}

To ensure the questionnaire validity, it was submitted to specialized jury members in the field of EFL curricula and instruction to judge the questionnaire items according to the following:

- Suitability of the questionnaire's items to measure students' perception towards their learning environment.

- Clarity of the questionnaire's items.

- Clarity of the questionnaire's instructions.

Some modifications were made according to the jury members' comments and suggestions. (To see the final version of the learning 
environment perception questionnaire, please go to appendix D.p 34).

\subsubsection{Internal Consistency}

The internal consistency was tested by calculating the correlation between the score given to each of the ten dimensions (teacher support, learner cohesiveness, involvement, investigation, task orientation, equity, curriculum, family support, social and cultural tradition of learning and input and output opportunities) and the total score of the questionnaire. The following is a detailed description of the previously mentioned correlation:

Table (1)

Correlation between the Questionnaire's Ten Dimensions and its Total Score

\begin{tabular}{|c|l|c|}
\hline No. & \multicolumn{1}{|c|}{ Dimensions } & $\begin{array}{c}\text { Correlation Value in Relation } \\
\text { to the Total Score }\end{array}$ \\
\hline \hline $\mathbf{1}$ & Teacher Support & $0.713^{* *}$ \\
\hline $\mathbf{2}$ & Learner Cohesiveness & $0.681^{* *}$ \\
\hline $\mathbf{3}$ & Involvement & $0.610^{* *}$ \\
\hline $\mathbf{4}$ & Investigation & $0.696^{* *}$ \\
\hline $\mathbf{5}$ & Task Orientation & $0.523^{* *}$ \\
\hline $\mathbf{6}$ & Equity & $0.381^{*}$ \\
\hline $\mathbf{7}$ & Curriculum & $0.537^{* *}$ \\
\hline $\mathbf{8}$ & Family Support & $0.410^{*}$ \\
\hline $\mathbf{9}$ & $\begin{array}{l}\text { Social and Cultural } \\
\text { Tradition of Learning }\end{array}$ & $0.459^{*}$ \\
\hline $\mathbf{1 0}$ & Input and Output & $0.626^{* *}$ \\
\hline \hline
\end{tabular}

*Correlation is significant at the 0.05 level.

**Correlation is significant at the 0.01 level.

The above table shows that there is a correlation between the questionnaire dimensions and its total score at the significance level $(0.05)$ and at the significance level (0.01). This means that the 
learning environment perception questionnaire has an acceptable level of validity.

\subsubsection{Reliability of the Questionnaire}

To determine the questionnaire reliability, it was administered to a group of 30 students, as a pilot study, in the first year-English Language Department at the Faculty of Education/Fayoum University rather than those participated in the current research. Cronbach's Alfa formula was used to estimate the questionnaire reliability. It was found (0.751) which is a high level of reliability.

\subsubsection{Time of the Questionnaire}

The needed time for the learning environment perception questionnaire was calculated, after applying the pilot study, by recording the number of minutes taken by each participant to finish the administered questionnaire and dividing them by the number of the participants. The average estimated time for responding to the questionnaire was $\mathbf{1 0}$ minutes.

\subsubsection{Scoring the Learning Environment Perception Questionnaire}

The final version of the questionnaire consisted of 27 items and the total score of the questionnaire was 135. Participants were given a score according to their responses out of "5" as following:

$1=$ "Almost never".

$2=$ "Seldom".

$3=$ "Sometimes".

$4=$ "Often".

$5=$ "Almost always".

\section{Research Instruments Implementation}

The writing proficiency test and the learning environment perception questionnaire were administered to a sample of (80) EFL pre-service teachers enrolled in the first year-English Language Department at the 
Faculty of Education/Fayoum University. The test and the questionnaire were administered to the sample on $\mathbf{1 1}^{\text {th }}$ of April 2019. Data were collected, recorded, and statistically analyzed to know the correlation between the EFL pre-service teachers' writing proficiency and their learning environment perception.

\section{Results}

\subsection{Testing the First Hypothesis of the Research}

The first hypothesis stated that:

"There is no statistically significant correlation between the scores obtained by the research participants in the writing proficiency test and in the learning environment perception questionnaire" According to the results in the following table, the above null hypothesis will be either confirmed or rejected.

Table (2)

The Correlation between the Writing Proficiency Test and the Learning Environment Perception Questionnaire

\begin{tabular}{|c|c|c|}
\hline & Writing Proficiency Test & $\begin{array}{c}\text { Learning Environment } \\
\text { Perception } \\
\text { Questionnaire }\end{array}$ \\
\hline \hline $\begin{array}{c}\text { Writing Proficiency } \\
\text { Test }\end{array}$ & 1 & $0.551^{* *}$ \\
\hline $\begin{array}{c}\text { Learning } \\
\text { Environment } \\
\text { Perception } \\
\text { Questionnaire }\end{array}$ & $0.551 * *$ & 1 \\
\hline
\end{tabular}

**means that correlation is significant at 0.01 level.

The table above shows that there is a positive statistically significant correlation between the scores obtained by the research participants in the writing proficiency test and in the learning environment perception questionnaire as the correlation coefficient value was (.551) which is significant at (0.01) level. Thus, the above null hypothesis is rejected. This result means that when the participants' 
writing proficiency increased, their learning environment perception increased as well.

\subsection{Testing the Second Hypothesis of the Research}

\section{The second hypothesis stated that:}

"There is no statistically significant correlation between the scores obtained by the research participants in the writing proficiency test and their scores obtained in the ten pivots of the learning environment perception questionnaire."

According to the results in the following table, the above null hypothesis will be either confirmed or rejected.

Table (3)

Correlation between the Writing Proficiency

Test and the Ten Dimensions of the Learning

Environment Perception Questionnaire

\begin{tabular}{|c|l|c||}
\hline No. & \multicolumn{1}{|c|}{ Dimensions } & $\begin{array}{c}\text { Correlation Value in Relation to the } \\
\text { Total Score of } \\
\text { the Writing Proficiency Test }\end{array}$ \\
\hline \hline $\mathbf{1}$ & Teacher Support & $.315^{* *}$ \\
\hline $\mathbf{2}$ & Learner Cohesiveness & $.491^{* *}$ \\
\hline $\mathbf{3}$ & Involvement & $.386^{* *}$ \\
\hline $\mathbf{4}$ & Investigation & $.400^{* *}$ \\
\hline $\mathbf{5}$ & Task Orientation & .174 \\
\hline $\mathbf{6}$ & Equity & .120 \\
\hline $\mathbf{7}$ & Curriculum & $.565^{* *}$ \\
\hline $\mathbf{8}$ & Family Support & $.328^{* *}$ \\
\hline $\mathbf{9}$ & $\begin{array}{l}\text { Social and Cultural Tradition } \\
\text { of Learning }\end{array}$ & $.455^{* *}$ \\
\hline $\mathbf{1 0}$ & $\begin{array}{l}\text { Input and Output } \\
\text { Opportunities }\end{array}$ & $.318^{* *}$ \\
\hline
\end{tabular}

**means that correlation is significant at 0.01 level. 
- The table above shows that there is a positive statistically significant correlation between the scores obtained by the research participants in the writing proficiency test and in the learning environment perception questionnaire regarding the teacher support dimension as the correlation coefficient value was (.315) which is significant at (0.01) level and it is a medium one. Thus, the above null hypothesis is rejected. This result means that when the students get the appropriate teacher support, their ability to write is improved.

- The table above shows that there is a positive statistically significant correlation between the scores obtained by the research participants in the writing proficiency test and in the learning environment perception questionnaire regarding the learner cohesiveness dimension as the correlation coefficient value was (.491) which is significant at (0.01) level and it is a medium one. Thus, the above null hypothesis is rejected. This result means that when there is learner cohesiveness, their ability to write is improved.

- The table above shows that there is a positive statistically significant correlation between the scores obtained by the research participants in the writing proficiency test and in the learning environment perception questionnaire regarding the involvement dimension as the correlation coefficient value was (.386) which is significant at (0.01) level and it is a medium one. Thus, the above null hypothesis is rejected. This result means that when the students are involved in the learning process, their ability to write is improved.

- The table above shows that there is a positive statistically significant correlation between the scores obtained by the research participants in the writing proficiency test and in the learning environment perception questionnaire regarding the investigation dimension as the correlation coefficient value 
was (.400) which is significant at (0.01) level and it is a medium one. Thus, the above null hypothesis is rejected. This result means that when the students are encouraged to investigate what they learn, their ability to write is improved.

- The table above shows that there is a positive statistically significant correlation between the scores obtained by the research participants in the writing proficiency test and in the learning environment perception questionnaire regarding the task orientation dimension as the correlation coefficient value was (.174) which is not significant at (0.01) level and it is a weak one. Thus, the above null hypothesis is confirmed. This result means that if the students know about the task aims and instructions, this will not increase their ability to write.

- The table above shows that there is a positive statistically significant correlation between the scores obtained by the research participants in the writing proficiency test and in the learning environment perception questionnaire regarding the equity dimension as the correlation coefficient value was (.120) which is not significant at (0.01) level and it is a weak one. Thus, the above null hypothesis is confirmed. This result means that if the students are equally treated, this will not increase their ability to write.

- The table above shows that there is a positive statistically significant correlation between the scores obtained by the research participants in the writing proficiency test and in the learning environment perception questionnaire regarding the curriculum dimension as the correlation coefficient value was (.565) which is significant at $\mathbf{( 0 . 0 1 )}$ level and it is a medium one. Thus, the above null hypothesis is rejected. This result means that when the students have an authentic interesting curriculum, their ability to write is improved. 
- The table above shows that there is a positive statistically significant correlation between the scores obtained by the research participants in the writing proficiency test and in the learning environment perception questionnaire regarding family support as the correlation coefficient value was (.328) which is significant at (0.01) level and it is a medium one. Thus, the above null hypothesis is rejected. This result means that when the students are supported by their families, their ability to write is improved.

- The table above shows that there is a positive statistically significant correlation between the scores obtained by the research participants in the writing proficiency test and in the learning environment perception questionnaire regarding the social and cultural tradition of learning dimension as the correlation coefficient value was $(\mathbf{. 4 5 5})$ which is significant at (0.01) level and it is a medium one. Thus, the above null hypothesis is rejected. This result means that if the students link between the taught material and their society, their ability to write is improved.

- The table above shows that there is a positive statistically significant correlation between the scores obtained by the research participants in the writing proficiency test and in the learning environment perception questionnaire regarding the input and output opportunities dimension as the correlation coefficient value was (.318) which is significant at (0.01) level and it is a medium one. Thus, the above null hypothesis is rejected. This result means that when the students are engaged in the learning process, their ability to write is improved.

\section{Discussion}

The previously stated results show that there is a positive relationship between the EFL pre-service writing proficiency and their perception 
of the learning environment. Their writing proficiency can be improved if their learning environment perception is changed and widened. In addition, the results showed that there are positive medium relationships between the improvement of the writing proficiency level and only eight dimensions of the EFL pre-service teachers' learning environment perception which are: (1) teacher support, (2) learner cohesiveness, (3) involvement, (4) investigation, (5) curriculum, (6) family support, (7) social and cultural tradition of learning, and (8) input and output opportunities. Yet, there are positive weak relationships between improving the writing proficiency level of the EFL pre-service teachers and the following two dimensions of the learning environment perception: (1) equity and (2) task orientation.

Some studies confirmed the findings that changing the learners' perceptions positively affects their learning in general and English learning in particular such as Khine (2001),Allen\&Fraser (2002), Goh (2005), Rita \& Dunlop (2011),Wei(2011), Neeman \& Barak (2013), Harris (2013), Alzubaidi, Albridge \& Khine (2016), Khine et al. (2017), Siddig \&Alkoudary (2018) and Ahmed et al. (2018).All these studies found out the positive influence of the learners' perceptions on their learning. Some of those studies depended on the same dimensions of the current research while others depended on similar dimensions. There are no previous studies and researches that directly handle the relationship between the EFL learners' writing proficiency and their learning environment perception.

\section{Conclusion}

The present research aimed at investigating the relationship between the EFL pre-service teachers' writing proficiency and their learning environment perception. Findings showed that there is a positive relationship between them. Also, the learning environment perception's dimensions except of equity and task orientation 
dimensions have a positive impact on the improvement of EFL preservice teachers' writing proficiency. Thus, EFL teachers or instructors and families should support the students to help them learn English as a foreign language in general and writing in particular. Moreover, students should be involved in the learning process.

\section{Recommendations}

In light of the current research findings and the discussion of these findings presented in the previous part, the following recommendations are reached:

1.English writing skill should be given more attention as a way of communication like the other language skills: the listening and the speaking skills especially for the EFL students.

2. The learning process should be learner-centered by giving students more opportunities to interact with each other and with their surrounding environment and community as they learn more when they are active learners.

3.It is highly recommended that, during the writing sessions, the students should be promoted to learn collaboratively through pair work, group work, discussions and negotiations.

4. The students should be provided with authentic assessments and a direct feedback including positive reinforcement and effective comments to support them to write more without being afraid and to avoid the repeated mistakes. 
Suggestions for Further Research

In light of the current research findings, the researcher suggests the following for further research:

1.Investigating the relationship between the EFL learning perception's dimensions and enhancing the other English Language skills: listening, reading and speaking.

2.Investigating the relationship between the EFL learning perception's dimensions and enhancing writing proficiency in other stages: primary and secondary stages in Egypt. 


\section{$\underline{\text { References }}$}

Ahmed,Y.,Taha,M.H.,Alneel,S.\&Gaffar,A.M.(2018).Students' perception of the learning environment and its relation to their study year and performance in Sudan. International Journal of Medical Education.(pp.145-150).

Aldridge,J.M.,Fraser,B.J.,Bell,L.\&Dorman,J.(2012).Using a new learning environment questionnaire for reflection in teacher action reseach. The Association for Science Teacher Education,USA,23(pp.259-290).

Allen,D.\&Fraser,B.J.(2002).Parent and student perceptions of the classroom learning environment and its influence on student outcomes. A paper presented at the annual meeting of the American Educational Research Association, New Orleans.

Ali,M.F.A.(2008).An investigation of proficient and less proficient EFL Arab learners' vocabulary learning strategies, linguistic self-image and perceptions of learning environment. Faculty of Education Journal, 8. Fayoum University . (pp.451-499).

Ali,M.F.A.\&Ammar,A.M.I.(2005).An investigation of the relationship between EFL pre-service teachers' epistemological beliefs and their learning strategies, teaching practices and foreign language classroom anxiety. Journal of Research in Education and Psychology,18(3),Minia University.

Alzubaidi,E.,Aldridge,J.M.\&Khine,M.S.(2014).Learning English as a second language at university level in Jordan: motivation, self-regulation and learning environment perceptions. Learning Environ Res, 19(pp.133-152) 
Barr,J.J.(2016).Developing a positive classroom climate. IDEA Paper 61.IDEA Center.

Business Dictionary.(Perception). Retrieved March 12 2019 from http:// www. Business dictionary. com /definition/perception.html

Cambridge Dictionaries Online. (Perception) Retrieved March $12^{\text {th }}$ 2019 from: http:// dictionary. cambridge.org/ dictionary /british/perception

Dunlop,C.S.M.(2004).Perceptions of the learning environment, attitudes towards science, and understandings of the nature of science among prospective elementary teachers in an innovative science course. Science and Mathematics Education Centre.

Fraser, B.J.(1998).Classroom environment instruments: development, validity and applications. Learning Environments Research, 1. (pp.7-33).

Goh,P.S.C.(2005).Perceptions of learning environments, learning approaches, and learning outcomes: A study of private higher education students in Malaysia from twinning programmes.

Harris,L.(2013).An examination of $8^{\text {th }}$ grade students perceptions of learning environment in relation to their academic performance.

Hayati,N.(2015).A study of language learning beliefs,strategies, and English academic achievement of the ESP students of STIENAS Samarinda.Dinamika Ilmu,15(2).

Hofer,B.K.(2000).Dimensionality and disciplinary differences in personal epistemology. Contemporary Educational Psychology, 25(4)(pp.378-405)

Huy,N.T.(2015).Problems affecting learning writing skill of grade 11 at Thong Linh high school. Asian Journal of Educational Research,3(2). 
Ismail,S.A.A.(2011).Exploring students' perceptions of ESL writing. Canadian Center of Science and Education,4(2) .

Khine,M.S.(2001).Using the WIHIC questionnaire to measure the learning environment. Teaching and Learning,22(2)(pp.54-61)

Khine,M.S.,Fraser,B.J.,Afari,E.,Oo,Z.\&Kyaw,T.T.(2017).Students' perceptions of the learning environment in tertiary science classrooms in Myanmar.

Klimova,B.F.(2013).The importance of writing. Indian Journal of Research-PARIPEX,2.(1).(pp. 9-11).

(2014).Detecting the development of language skills in current English language teaching in the Czech Republic. Procedia-Social and Behavioral Sciences, 158(pp.85-92)

Lizzio,A.,Wilson,K.\&Simons,R.(2002).University students' perceptions of the learning environment and academic outcomes: implications for theory and practice. Studies in Higher Education, 27 (1).

Mastan,M.E.B,Maarof,N.\&Embi,M.A.(2017).The effect of writing strategy instruction on ESL intermediate proficiency learners' writing performance. Journal of Educational Research and Review, 5(5).(pp.71-78).

Nacira,M.G.(2010).Identification and analysis of some factors behind students' poor writing productions: the case study of $3^{\text {rd }}$ year students at the English department -Batna University.

Neeman,Y.P.\&Barak,M.(2013).Exploring students' perceptions about learning in school: An activity theory based study. Journal of Education and Learning, 2(3).

\section{3}


Nijhuis,J.F.H.(2006).Learning strategies ,students' characteristics and their perceptions of the learning environment: An integrated study among business students.

Nik,Y.A.,Hamza,A.\&Rafidee,H.(2010).A comparative study on the factors affecting the writing performance among bachelor students. International Journal of Educational Research and Technology, 1 (1) (pp.5459).

Nik,Y.A.,Sani,B.B.,Chik,M.N.B.W.,Jusoff,K.\&Hasbollah,H.R.B.(201 $0)$. The writing performance of undergraduates in the university of technology Mara, Terengganu, Malaysia. Journal of Languages and Culture, 1(1).(pp.8-14).

Partnership's $21^{\text {st }}$ Century Skills Framework. Retrieved from : www.p21.org

Rad,N.F.(2010).Evaluation of English students' beliefs about learning English as foreign language: A case of Kerman Azad university. A paper published in International Conference "ICT for Language Learning" $3^{\text {rd }}$ edition. Rao,V.Ch.S.(2016).A brief study of English language proficiency:employability. English for Specific Purposes World,49(17).

Reichelt, M., Lefkowitz, N., Rinnert, C.\& Schultz,J.M. (2012).Key issues in foreign language writing. Foreign Language Annals, 45 (1), (pp. 22-41).American Council on the Teaching of Foreign Languages.

Rita,R.D.\&Dunlop,C.S.M.(2011).Perceptions of the learning environment and associations with cognitive achievement among gifted biology students. Learning Environ Research,14.(pp.25-38). 
Siddig,B.E.\&Alkhoudary,Y.A.(2018). Investigating classroom interaction: teacher and learner perception. English Language Teaching, 11(12).

Smith,R.K.(2004).Give them what they want: using student perception of teacher behavior to create the ideal classroom environment.

Walish,K.(2010).The importance of writing skills: online tools to encourage success. Retrieved on March $2^{\text {nd }}, 2019$ from https://www.emergingedtech.com/2010/11/theimportance-of-writing-skills-online-tools-toencourage-success/

Wei,L.S.(2011).Relationship between students' perceptions of classroom environment and their motivation in learning English language. International Journal of Humanities and Social Science,1 (21). 


\section{Appendices}

Appendix $A$

List of the Jury Members

List of Jury Members

\begin{tabular}{|c|c|}
\hline Name & Position \\
\hline \multicolumn{2}{|c|}{ Minia University } \\
\hline Dr.Gamal Shehata & $\begin{array}{l}\text { Professor of Curriculum and EFL } \\
\text { Instruction-Faculty of Education }\end{array}$ \\
\hline \multicolumn{2}{|c|}{ Ain Shams University } \\
\hline Dr.Zeinab El-Naggar & $\begin{array}{l}\text { Professor Emerita of Curriculum and } \\
\text { EFL Instruction-Faculty of Education }\end{array}$ \\
\hline Dr.Magdy Mahdy & $\begin{array}{l}\text { Professor of Curriculum and EFL } \\
\text { Instruction-Faculty of Education }\end{array}$ \\
\hline \multicolumn{2}{|c|}{ Fayoum University } \\
\hline Dr.Mona Ahmed Abdel Tawab & $\begin{array}{l}\text { Lecturer of Curriculum and EFL } \\
\text { Instruction-Faculty of Education }\end{array}$ \\
\hline Dr.Sayed El-Garhy & $\begin{array}{c}\text { Assistant Professor of Mental Health- } \\
\text { Faculty of Education }\end{array}$ \\
\hline
\end{tabular}




\section{Appendix B \\ Writing Proficiency Test \\ Test Instructions}

Name:

Student's Mark:

Dear Students, please read the following instructions before you start answering the test:

1. Write your name in the space above.

2. Read each question carefully before you answer.

3. Answer the questions in the provided space.

4. Duration of the test is 45 minutes.

5. Total mark of the test is $\mathbf{1 0 0}$ marks. 
Time:45 minutes.

Mark: $\quad$ /100 Marks.

1-Imagine that you would work in the summer vacation. You wanted to convince your friend to come with you. It would be a part-time job as a teacher in Alexandria. Write not less than eight sentences to convince him/her. You can use the following guiding ideas. ( $/ 25$ Marks)

-Gaining experience.

-Acquiring new skills.

-Meeting different persons.

2-One of your colleagues gains weight and he/she asks for your advice. Write for him/her some pieces of advice. Write not less than eight sentences. You can use the following pictures.

/25 Marks)
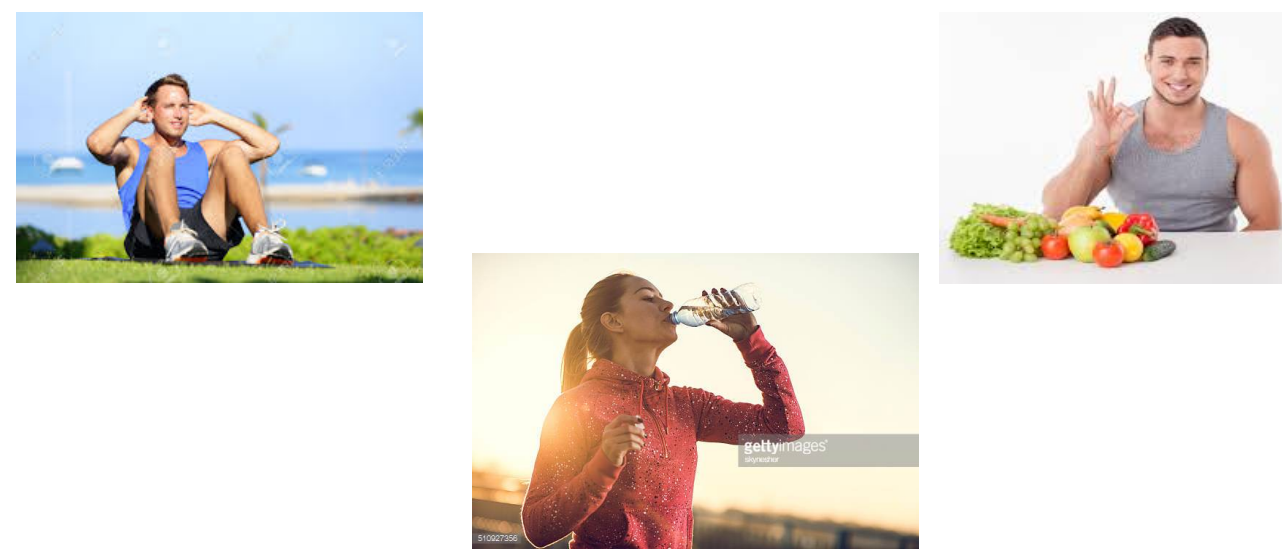
3-You want to apply for a teacher's job in an international school. For applying, write a brief introduction about yourself in not less than eight sentences. You can use the following ideas. Marks)

* Your full name.

*Your age.

*Your qualifications.

*Training courses.

*Your skills.

4-Write about the following: "Which is better to spend your free time alone or with your friends?". Try to give reasons. Write not less than eight sentences.
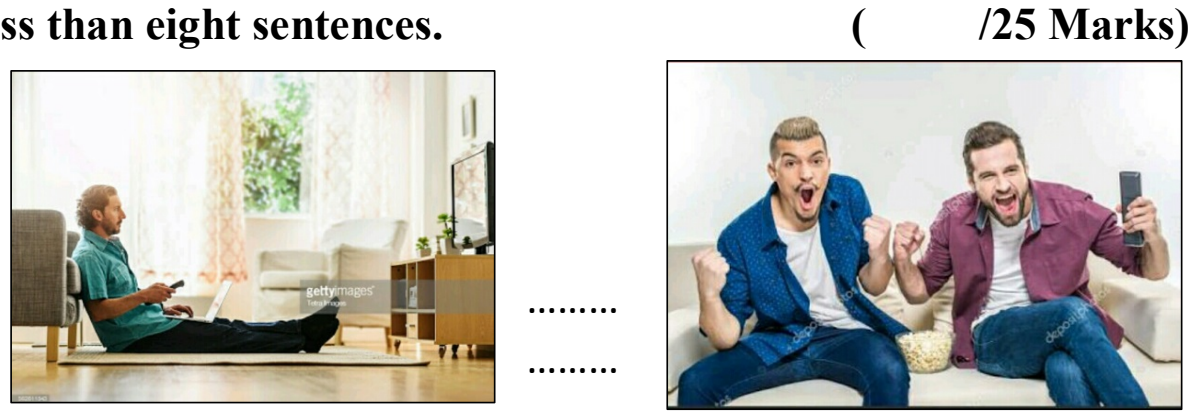
Appendix C

Writing Scoring Rubric

The Writing Scoring Rubric

\begin{tabular}{|c|c|c|c|c|c|c|}
\hline \multicolumn{7}{|c|}{ Scoring Criteria } \\
\hline 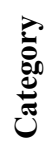 & $\begin{array}{c}\text { Indicators } \\
\text { of the } \\
\text { Writing } \\
\text { Sub-Skills }\end{array}$ & $\begin{array}{c}\text { Excelle } \\
\text { nt } \\
(5)\end{array}$ & $\begin{array}{c}\text { Very Good } \\
\text { (4) }\end{array}$ & $\begin{array}{c}\text { Average } \\
\text { (3) }\end{array}$ & $\begin{array}{c}\text { Acceptable } \\
\text { (2) }\end{array}$ & $\begin{array}{c}\text { Weak } \\
\text { (1) }\end{array}$ \\
\hline 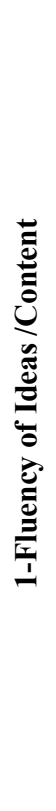 & $\begin{array}{l}\text { a-Writing } \\
\text { not less } \\
\text { than eight } \\
\text { sentences } \\
\text { for a topic. } \\
\text { b- Setting } \\
\text { the main } \\
\text { idea and } \\
\text { relevant } \\
\text { supporting } \\
\text { details } \\
\text { clearly. } \\
\text { c- } \\
\text { Providing } \\
\text { enough } \\
\text { details and } \\
\text { examples to } \\
\text { make ideas } \\
\text { understand } \\
\text { able. }\end{array}$ & $\begin{array}{l}\text {-Writing } \\
\text { more } \\
\text { than } \\
\text { eight } \\
\text { sentenc } \\
\text { es for a } \\
\text { topic. } \\
\text { - Main } \\
\text { idea is } \\
\text { clear, } \\
\text { suppor } \\
\text { ted and } \\
\text { enriche } \\
\text { d by all } \\
\text { relevan } \\
\text { t } \\
\text { details } \\
\text { and } \\
\text { exampl } \\
\text { es. }\end{array}$ & \begin{tabular}{|l} 
- Writing \\
seven to \\
eight \\
sentences \\
only for a \\
topic. \\
- Main idea \\
is showed \\
by details, \\
but they \\
are not \\
enriched \\
by \\
examples.
\end{tabular} & $\begin{array}{l}\text { Writing five to } \\
\text { six sentences } \\
\text { only for a } \\
\text { topic. } \\
\text { - Topic or } \\
\text { theme is } \\
\text { identified as a } \\
\text { main idea, but } \\
\text { there are } \\
\text { limited details } \\
\text { and there are } \\
\text { no examples. }\end{array}$ & $\begin{array}{l}\text { Writing three } \\
\text { to four } \\
\text { sentences only } \\
\text { for a topic. } \\
\text { - Main idea is } \\
\text { still missing } \\
\text { through the } \\
\text { topic or the } \\
\text { theme. } \\
\text { - There are only } \\
\text { a few details } \\
\text { and the length } \\
\text { of the topic is } \\
\text { not adequate } \\
\text { for } \\
\text { development. }\end{array}$ & $\begin{array}{l}\text { - Writing less } \\
\text { than three } \\
\text { sentences for } \\
\text { a topic. } \\
\text { - There is no } \\
\text { main idea or } \\
\text { central } \\
\text { theme. } \\
\text { - There are no } \\
\text { supporting } \\
\text { details or } \\
\text { examples. } \\
\text { - The ideas are } \\
\text { not clear. }\end{array}$ \\
\hline
\end{tabular}


Scoring Criteria

\begin{tabular}{|c|c|c|c|c|c|c|}
\hline 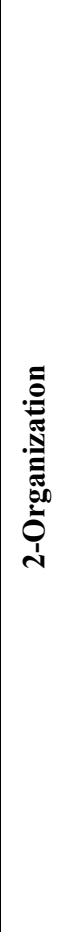 & $\begin{array}{l}\text { a- Setting } \\
\text { the } \\
\text { beginning, } \\
\text { the middle } \\
\text { and the end } \\
\text { of the } \\
\text { written } \\
\text { topic } \\
\text { definitely. } \\
\text { b- Using } \\
\text { suitable } \\
\text { transitions, } \\
\text { logical } \\
\text { connectors } \\
\text { and } \\
\text { adequate } \\
\text { coherence } \\
\text { markers for } \\
\text { ensuring } \\
\text { smooth flow } \\
\text { of logical } \\
\text { sequence of } \\
\text { ideas. }\end{array}$ & $\begin{array}{l}\text { - Writing } \\
\text { has a } \\
\text { definite } \\
\text { beginni } \\
\text { ng, } \\
\text { middle } \\
\text { and an } \\
\text { end. } \\
\text { - Ideas } \\
\text { are } \\
\text { related } \\
\text { and } \\
\text { well- } \\
\text { connec } \\
\text { ted by } \\
\text { using } \\
\text { suitabl } \\
\text { e } \\
\text { transiti } \\
\text { ons } \\
\text { effectiv } \\
\text { ely. }\end{array}$ & $\begin{array}{l}\text { - Writing } \\
\text { follows a } \\
\text { clear } \\
\text { sequence } \\
\text { with a } \\
\text { beginning, } \\
\text { middle and } \\
\text { an end. } \\
\text { - Few ideas } \\
\text { may not be } \\
\text { related to } \\
\text { each other. } \\
\text { - Most } \\
\text { transitions } \\
\text { are } \\
\text { adequate } \\
\text { and } \\
\text { logical, but } \\
\text { they are } \\
\text { repetitive. }\end{array}$ & $\begin{array}{l}\text { - Writing shows } \\
\text { minimal } \\
\text { evidence of } \\
\text { logical } \\
\text { sequence. } \\
\text { - Writing has a } \\
\text { definite } \\
\text { beginning, } \\
\text { but the end is } \\
\text { inappropriate } \\
\text { or it has a } \\
\text { definite end, } \\
\text { but the } \\
\text { beginning is } \\
\text { inappropriate } \\
\text { - } \\
\text { - There is a } \\
\text { limited use of } \\
\text { transitions or } \\
\text { they are not } \\
\text { used } \\
\text { appropriately }\end{array}$ & $\begin{array}{l}\text { Writing shows } \\
\text { little evidence } \\
\text { of logical } \\
\text { sequence. } \\
\text { - Writing has } \\
\text { several ideas } \\
\text { that are not } \\
\text { related to each } \\
\text { other. } \\
\text { - Writing lacks } \\
\text { clear } \\
\text { transitions } \\
\text { and ideas are } \\
\text { still } \\
\text { disconnected. }\end{array}$ & $\begin{array}{l}\text { - Writing is } \\
\text { haphazard. } \\
\text { - Writing does } \\
\text { not have } \\
\text { related } \\
\text { ideas. } \\
\text { - Transitions } \\
\text { are missing. } \\
\text { - Writing is } \\
\text { confusing } \\
\text { and hard to } \\
\text { follow. }\end{array}$ \\
\hline 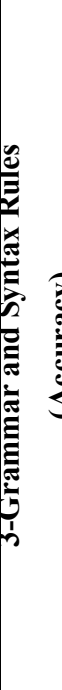 & $\begin{array}{l}\text { a- Using } \\
\text { grammatica } \\
\text { lly correct } \\
\text { sentences } \\
\text { (appropriat } \\
\text { e tense- } \\
\text { subject/ver } \\
\text { b } \\
\text { agreement- } \\
\text { preposition } \\
\text { s-pronouns- } \\
\text { conjunction } \\
\text { s, etc.) } \\
\text { b-Applying } \\
\text { correct } \\
\text { sentence } \\
\text { structures }\end{array}$ & $\begin{array}{l}\text { - Using } \\
\text { correct } \\
\text { gramm } \\
\text { atical } \\
\text { rules. } \\
\text { - Applyin } \\
\text { g } \\
\text { sentenc } \\
\text { e } \\
\text { structu } \\
\text { res } \\
\text { correctl } \\
\text { y. }\end{array}$ & $\begin{array}{l}\text { - Making } \\
\text { one or two } \\
\text { grammatic } \\
\text { al errors } \\
\text { related to } \\
\text { the } \\
\text { grammatic } \\
\text { al rules and } \\
\text { the } \\
\text { sentence } \\
\text { structures. }\end{array}$ & $\begin{array}{l}\text { Making three } \\
\text { or four } \\
\text { grammatical } \\
\text { errors related } \\
\text { to the } \\
\text { grammatical } \\
\text { rules and the } \\
\text { sentence } \\
\text { structures. }\end{array}$ & $\begin{array}{l}\text { Making six } \\
\text { grammatical } \\
\text { errors related } \\
\text { to the } \\
\text { grammatical } \\
\text { rules and the } \\
\text { sentence } \\
\text { structures. }\end{array}$ & $\begin{array}{l}\text { - There are } \\
\text { many } \\
\text { grammatical } \\
\text { errors more } \\
\text { than six that } \\
\text { negatively } \\
\text { affect } \\
\text { communicati } \\
\text { on and } \\
\text { writing is } \\
\text { distracting. }\end{array}$ \\
\hline
\end{tabular}




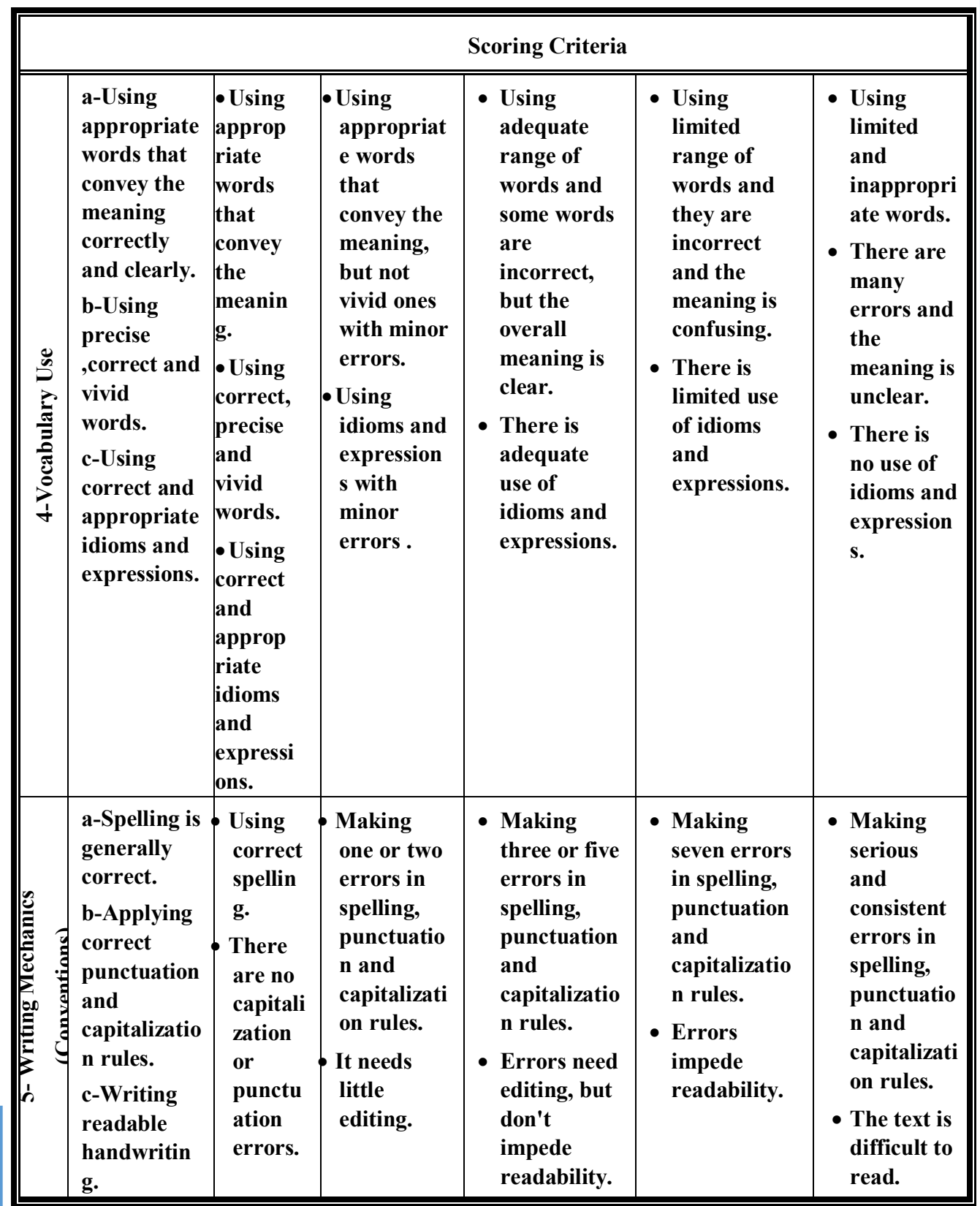




\section{Appendix D}

\section{Learning Environment Perception Questionnaire}

\section{The Learning Environment Perception Questionnaire}

The following are statements for finding out how you perceive your learning environment. There is no right or wrong answer of these statements. You are kindly requested to respond to each statement by ticking:

1: if it is "Almost never".

3: if it is "Sometimes".

5: if it is "Almost always".

\begin{tabular}{|c|c|c|c|c|c|c|}
\hline No. & Statements & $\begin{array}{c}\text { Almost } \\
\text { never }\end{array}$ & Seldom & Sometimes & Often & $\begin{array}{l}\text { Almost } \\
\text { always }\end{array}$ \\
\hline \multicolumn{7}{|c|}{ Teacher Support } \\
\hline \multicolumn{7}{|c|}{ (Extent to which the teacher helps, trusts and shows interest in students) } \\
\hline 1 & $\begin{array}{l}\text { My instructor encourages } \\
\text { me to express my } \\
\text { opinions and ideas freely } \\
\text { in a friendly atmosphere. }\end{array}$ & & & & & \\
\hline 2 & $\begin{array}{l}\text { My instructor is } \\
\text { interested in reading my } \\
\text { written topics. }\end{array}$ & & & & & \\
\hline 3 & $\begin{array}{l}\text { My instructor asks me to } \\
\text { watch T.V. channels and } \\
\text { listen to audio parts in } \\
\text { English. }\end{array}$ & & & & & \\
\hline \multicolumn{7}{|c|}{ Learner Cohesiveness } \\
\hline 4 & $\begin{array}{l}\text { I can make mistakes } \\
\text { while writing without } \\
\text { being afraid or shy in the } \\
\text { classroom. }\end{array}$ & & & & & \\
\hline 5 & $\begin{array}{l}\text { I can work with my } \\
\text { colleagues in a group to } \\
\text { finish a task. }\end{array}$ & & & & & \\
\hline 6 & $\begin{array}{l}\text { My colleagues and I } \\
\text { encourage each other to } \\
\text { finish a task in a perfect } \\
\text { way. }\end{array}$ & & & & & \\
\hline
\end{tabular}




\begin{tabular}{|c|c|c|c|c|c|c|}
\hline No. & Statements & $\begin{array}{l}\text { Almost } \\
\text { never }\end{array}$ & Seldom & Sometimes & Often & $\begin{array}{l}\text { Almost } \\
\text { always }\end{array}$ \\
\hline
\end{tabular}

Involvement

(Extent to how much the learners interested in classes and participate in discussions )

7 I feel that I am encouraged in the different stages of the lesson.

8 I am interested in the writing course.

9 I feel that I am a part of the learning process.

Investigation

(Extent to the focus on the skills of searching for information and solving problems)

10 My instructor encourages me to use the internet or even ask each other to know about the current events.

11 I do not depend only on the course's book to know information.

12 Some tasks require me to think critically.

\begin{tabular}{|l|l|l|l|l}
\hline & & & & \\
& & & & \\
\hline & & & & \\
\hline & & & & \\
\hline
\end{tabular}


An Investigation of the Relationship between

EFL Pre-Service Teachers' Writing Proficiency

and their Learning Environment Perception

\begin{tabular}{|c|c|c|c|c|c|c|}
\hline No. & Statements & $\begin{array}{c}\text { Almost } \\
\text { never }\end{array}$ & Seldom & Sometimes & Often & $\begin{array}{l}\text { Almost } \\
\text { always }\end{array}$ \\
\hline & classroom. & & & & & \\
\hline 17 & $\begin{array}{l}\text { The instructor's talking } \\
\text { time is less than our } \\
\text { talking time in the } \\
\text { classroom. }\end{array}$ & & & & & \\
\hline
\end{tabular}

Curriculum

(Extent to what the students learn through the course)

18 Curriculum does not depend only on a book, but there are other sources like video segments, pictures, the internet,etc.

19

The curriculum is interesting and helps me to improve my writing performance.

Family Support

(Extent to the relationship between the students and their parents)

20 My parents encourage me to use the internet to watch video segments and read about different topics.

21 My parents support me to buy English magazines, newspapers and books in English.

\section{Social and Cultural Tradition of Learning}

(Extent to the link between the course, the society and the culture)

22 I feel that I am a part of my society through the course.

23 The course links between our culture and other different cultures.

24 My friends and $I$ find it embarrassing and difficult to use the foreign language outside the classroom. 


\begin{tabular}{||l|l|l|l|l|l|l||}
\hline No. & \multicolumn{1}{|c|}{ Statements } & $\begin{array}{c}\text { Almost } \\
\text { never }\end{array}$ & Seldom & Sometimes & Often & $\begin{array}{c}\text { Almost } \\
\text { always }\end{array}$ \\
\hline \hline \multicolumn{7}{|c||}{ Input and Output Opportunities } \\
\hline 25 & $\begin{array}{l}\text { My instructor focuses on } \\
\text { learning by doing. }\end{array}$ & $\begin{array}{l}\text { My instructor motivates us } \\
\text { to socialize inside and } \\
\text { outside the classroom. }\end{array}$ & & & & \\
\hline 27 & $\begin{array}{l}\text { I have a direct feedback } \\
\text { after finishing any task. }\end{array}$ & & & & & \\
\hline
\end{tabular}




\section{المستخلص}

العنوان: دراسة العلاقة بين الإققان الكتابي لمعلمي اللغة الإجليزية كلغة أجنبية قبل الخدمة و إدر اكهم لبيئة التعلم

يهدف البحث الحالي إلى دراسة العلاقة بين الإتقان الكتابي لمعلمي اللغة الإنجليزية كلغة

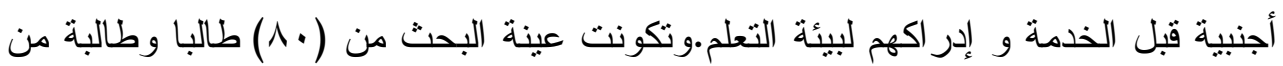
طلاب قسم اللغة الإنجليزية كلغة أجنبية بالفرقة الأولى -كلية التزبية-جامعة الفيوم. تم جمع البيانات من خلال إستخدام أداتين تم تصميمهم من قبل الباحثة : إختبار إتقان الكتابة الإنة و إستبانة إدر الك بيئة التعلم.وأظهرت النتائج وجود علاقة موجبة بين إتقان أفراد العينة للكتابة و بين إدر اكهم لبيئة التعلم.ونم تقديم مجموعة من التوصيات و المقترحات للمزيد

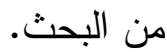

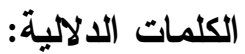

إتقان الكتابة، إدرالك بيئة التعلم، معلمي اللفة الإنجليزية كلفة أجنبية قبل

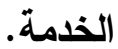

